\title{
Die Überprüfung des Unionsrechts am Maßstab der EMRK
}

Individualgrundrechtsschutz im Anwendungsbereich des Unionrechts unter den Vorzeichen des Beitritts der EU zur EMRK

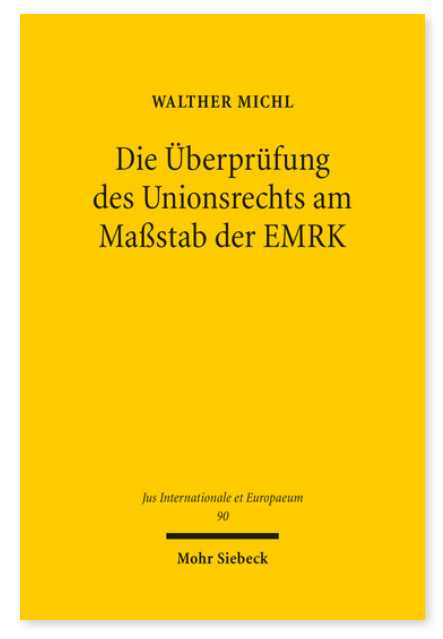

2014. XXII, 273 Seiten. JusIntEu 90

ISBN 978-3-16-152625-1

DOI 10.1628/978-3-16-152625-1

eBook PDF $74,00 €$

ISBN 978-3-16-152620-6

fadengeheftete Broschur 74,00€
Walther Michl behandelt das Verhältnis zwischen dem EU-Recht und der EMRK. Er legt dar, wie die Rechtsprechung des EuGH und des EGMR das Bedürfnis für eine externe Kontrolle des Unionshandelns am Maßstab der EMRK geweckt hat. Außerdem beleuchtet er, welche Erwartungen und Anforderungen unionsrechtlich mit der Verpflichtung der EU zum Konventionsbeitritt (Art. 6 Abs. 2 EUV) verbunden sind. Vor diesem Hintergrund wirft er einen Blick auf das Herzstück der künftigen Verbindung zwischen EU und EMRK: Er unterzieht den vorgesehenen Ablauf des Individualbeschwerdeverfahrens in Angelegenheiten mit Bezug zum EU-Recht einer kritischen Würdigung. Abschließend untersucht der Autor unter Einbeziehung der neuesten Rechtsprechung zur Grundrechtecharta, wie die EMRK materiell in das unionsrechtliche Mehrebenensystem eingepasst wird.

Walther Michl Geboren 1984; Studium der Rechtswissenschaften an der LMU; Masterstudium zum LL.M. in European Law am King's College London; 2012 zweites Staatsexamen; 2006-08 studentische Hilfskraft am Lehrstuhl für Öffentliches Recht und Europarecht der LMU München; seit 2008 wissenschaftlicher Mitarbeiter ebendort.
Jetzt bestellen:

https://mohrsiebeck.com/buch/die-ueberpruefung-des-unionsrechts-am-massstab-der-emrk-9783161526251?no_cache=1 order@mohrsiebeck.com

Telefon: +49 (0)7071-923-17

Telefax: +49(0)7071-51104 